International Journal of Biology, Pharmacy and Allied Sciences (IJBPAS) 'A Bridge Betueen Caboratory and QRendo'

WwW.iibpas.com

\title{
AWARENESS AND ATTITUDE OF POST GRADUATES TOWARDS CHANGING CLIMATE AND ENVIRONMENT SPECIFIC TO NORTH EAST INDIA
}

\author{
R.D.PADMAVATHY \\ Assistant Professor in Mathematics Education, Department of Education, Tezpur University \\ (A Central University), Assam \\ "Corresponding Author: Dr. R.D.Padmavathy: E Mail: padmajothi@yahoo.in

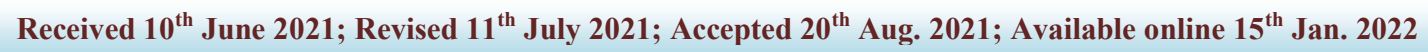 \\ https://doi.org/10.31032/IJBPAS/2022/11.1.1061
}

\begin{abstract}
In worldwide changing climate affect the people and the environment. Though changing climate occur because of human actions and natural factors an over decades, now it has become as a major challenges which affects the life styles of all the living beings as well as the environment. UNEP focuses four keys goals as adopting, mitigating, reducing emission and enhancing knowledge and awareness. Recognising the knowledge towards protection of the environment is the first step of emergence of conservation of the environment. Keeping this in view researcher try to highlights two issues in this paper (i) The impact of changing climate on the natural, economic, social, environment and human health prospective in India. (ii) In this paper an attempt was made to identify post graduate students awareness and attitude towards changing climate and environment present. For that survey was conducted among 360 post graduate students by adopting random sampling technique using Taj environmental attitude scale and Climate change awareness scale constructed by researcher was used to collect the data. Post graduate student's knowledge, awareness and attitude towards environment and climate change were quite high. They show high awareness about climate change issues, attitude about the polluters and its impacts on environment concern and human. At the same time they show low awareness towards climate change and natural disasters, low attitude towards
\end{abstract}


forests, wild life, population explosion, health and hygiene related issues. Post graduate student's awareness related to those issues was less compared to others areas. Many of the post graduate students don't feel forest, wildlife and its conservation and preservation greater importance for life and maintenance of bio diversity. In the same way they don't think or aware about the population explosion related problems and issues.

\section{Keywords: Environment, Climate, Change, Attitude, Post graduates}

\section{INTRODUCTION}

Changing climate is one of the major threat and challenges we face in our time and most challenging task to attain sustainable development. In 2015 United Nations established 17 SDG goals, Climate action is SDG's $13^{\text {th }}$ goal. SDG 13 start to achieve by 2030 with five targets one among them is build knowledge improve education, awareness raising and human capacity on climate change mitigation, adaptation, impact reduction and early warning (United Nations,2017).

The unexpected or unusual weather patterns in earth climate create change includes increased temperature, humidity, wind, gases, water, land, air, snow, rising sea levels, flooding and food production etc., over many years of any area. It gives more stress and threatens to the environment as well as the human life. As pointed out by UNEP (2010) without taking any drastic action today, adapting to these impacts in the future will be more difficult and costly".

Sustainable development emphasising the complex links between social, economic, political and environmental factors, introduces a new layer of dilemmas to the issues of equity and environment. It emphasise the importance of democracy in solving environmental problem. The significance of sustainable development is that by showing how environmental problems are inextricable link to economic and social inequalities, it has brought development issues to the forefront of the environmental debate" (Prasad, 2015). Brundtland Commission World Commission, (1987) remarked "Sustainable development is development that meets the needs of the present without compromising the ability of future generations to meet their own needs. Climate change sub programme UNEP focuses four keys goals as adopting, mitigating, reducing emission from deforestation and forest degradation and enhancing knowledge and awareness. Recognising the knowledge towards protection of the environment is the first step of emergence of conservation of the environment. In this paper researcher try to highlights two issues in this paper (i) The impact of changing climate on the natural, 
economic, social, environment and human health prospective in India. (ii) In this paper an attempt was made to identify the knowledge, awareness and attitude level of present post graduate students.

\section{Impact of changing climate in nature and environment}

India has 'Tropical Monsoon' climate with seasonal reversal of the winds during the course of the year. In India due to changing climate the annual monsoons becomes unpredictable. As rightly remarked by Mohapatra, Director general of Meteorology "the heavy rainy days has increased, monsoon is increasingly erratic, interspersed with extreme weather events, and the frequency of light rainy days have decreased. This extreme weather events are clear cut result of climate change"(Sarkar,2021). There are few events listed to show the uncommon trend exhibited in India due to consequences of changing climate in nature.

\section{High Heat Wave}

Changing climate produces hot weather which caused death of 1677 people passed away in 1955, In Ahmadabad 1300 people died in the month of May 2010, 793 people in 2011, 1247 in 2012, and 1216 people in 2013. In May 2015 the causalities were unusual and abnormal pre-monsoon rain season showers ends produced a high heat wave leads 2500 persons death in Andhra Pradesh and Telegana (1345), Punjab, Uttarpradesh, Odisha and Bihar (The Hindu,2015). As reported by Jamwal (2014) in 2009, the Indian Meteorological Department's Mumbai office found that the 1990s witnessed a three-fold rise in natural disasters such as floods and thunderstorms when compared to the 1960s disasters has increased nine-fold in addition it found a Mumbai's average maximum temperature rise of $1.62^{\circ} \mathrm{C}$. By 2016 the temperature increased $51^{\circ} \mathrm{c}$ and 1600 people lost their lives and by 2019 temperature increased $50.8^{\circ} \mathrm{c}$ and 184 people lost their lives.

\section{Extreme Rain, Flood and Landslides}

In $20^{\text {th }}$ century the worst floods occurred in Chennai (1943), Gujarat(1979), Bihar(1987), Punjab (1988) and Eight states of India (1993). The Pune-based Indian Institute of Tropical Meteorology analysed data of more than 1,800 weather stations in central India from 1951 to 2000 and found that the number of extreme events - rainfall exceeding $150 \mathrm{~mm}$ per day - has doubled since the early 1950s. Heavy rainfall, exceeding $100 \mathrm{~mm}$ per day, shows a 10 percent increase per decade"

In $21^{\text {st }}$ century the worst floods occurred in North East India specifically Assam gets susceptible recurrent rainfall, serious flood and landslides in 2012, 2013, 2015, 2016, 2017, 2018, 2019 and five people 
died, 16000 are displaced in 2020. In the same way two major flood disasters occurred in Uttarkhant (2015, 2021) and Jammu \& Kashmir(2014) [Table 1].

Comparing $20^{\text {th }}$ century the worst floods occurred in $21^{\text {st }}$ century has increased Tsunami, Earth quakes, Rivers Disappear, Sea Level Rise and Mountain Decline

Professor McGuire rightly pointed out that "In the political community people are almost completely unaware of any geological aspects to climate change. Changing climate doesn't just affect the atmosphere and the oceans only but the earth's crust as well....when the ice is lost, the earth's crust bounces back up again and that triggers earthquakes, which trigger submarine landslides, which cause tsunamis. Tony Song of NASA's Jet Propulsion Laboratory in California warned of the vast power of recently discovered "glacial earthquakes" -- in which glacial ice mass crashes downwards like an enormous landslide "Our experiments show that glacial earthquakes can generate far more powerful tsunamis than undersea earthquakes with similar magnitude" (Meares, 2009). In India prior to Dec 26, 2004 no Indian people were aware or scared of the word 'tsunami' and there were no records found about tsunami occurred on the south west coast of India. As a result of unusual Indian Ocean Earthquakes moves epicentre below the seawater of occurred was the root cause for the tsunami attack in twenty three locations of Tamilnadu coast got affected and more than 8000 people missed their life for the giant wave. Tsunami severely affect the southern coastal regions of the eastern state of Tamilnadu and Pondicherry" (Sheth, 2006). Nepal earthquake happened on April 25, 2015 with magnitude 7.8 approximately more than 8000 dead and made many people homeless and lifeless, it badly damages the life of every people. Sea level rise leads to flood, salty water into ground water and spoils the nature of ground water sources, lakes and aquatic eco system. According to the Intergovernmental Panel on Climate Change, sea levels in India are expected to rise at the rate of $2.4 \mathrm{~mm}$ a year; in 2050 , the total increase will be $38 \mathrm{~cm}$, displacing tens of thousands of people. For nearly $25 \%$ of India's population living along the coast, global warming is a question of survival rather than a scientific theory. The UN second working report predicts huge coastal erosion by rising sea levels (about $40 \mathrm{~cm}$ ) resulting from faster melting glaciers in the Himalaya Hindukush ranges. In consonance with that R.K.Pachauri, chairperson of the IPCC reveals "It could adversely affect half-amillion people in India because of excessive flooding in coastal areas, and it can increase 
salinity of groundwater in the Sunder bans and surface water in coastal areas" (Mahapatra 2015).

\section{Impact of Changing climate on Indian}

\section{Economic and Agriculture}

Changing climate has a direct impact on economic condition of India at the same time it indirectly affects the social conditions of human society. Another major threat changing climate posed to human society is decline of agriculture fields, lands, seasons and crops.

India has more than 157 million hectares agricultural land with more than 65 percent of people's main job is related agriculture, forestry and fisheries and these fields contribute to the increase of GDP. Agriculture plays an important role in Indian economy. As per The Economic Survey 201415 and IBEF report "with 20 agri-climatic regions, all 15 major climates in the world exist in India. India is the largest producer of spices, pulses, milk, tea, cashew and jute; and the second largest producer of wheat, rice, fruits and vegetables, sugarcane, cotton and oilseeds. Further, India is second in global production of fruits and vegetables, and is the largest producer of mango and banana. It also has the highest productivity of grapes in the world". The lockdown induced due to Covid19 raised an unpredictable challenge in the agricultural sector and lead path for demand and supply disruptions.

Agriculture is a source of livelihood for 65 percent of the GDP, adverse impact on agriculture would have serious effect on the economy, food security and health of any country. It has been estimated that 0.5 degree rise in the temperature would result in reduction of wheat yields by 10 percent. In similar Economic Survey 2014-15 and IBEF report "with 20 agri-climatic region Indian Agricultural Research Institute (IARI) warns that a $1^{\circ} \mathrm{C}$ increase in temperature may reduce yields of wheat, soybean, mustard, groundnut and potato by 3-7 percent. It says productivity of most crops will decrease only marginally by 2020, but the decline will touch 10-40 percent by 2100 . The rising temperature and heat will directly impact livestock, leading to animal stress and reduced milk yield - a loss of 1.5 million tonnes of milk by 2020 . In consonance with the above findings IPCC Third Assessment Report, 2001 revealed that warming more than 3 degree Celsius is expected to have negative effect on production in all regions and changing climate would hit the poorest countries severely in terms of reducing agricultural products, and due to scarcity of water crop yield would be reduced and south Asia loses many regional staples like rice, millet, maize could top 10 percent by 
2030. "In March 2014, freak hailstorms hit central and north India, destroying at least 5.5 million hectares of ready-to-harvest rabi crops. WGII paints a dark picture for Indian agriculture, predicting losses of over $\$ 7$ billion (around Rs 42,749 crore) in 2030. It foresees a 2-14 percent reduction in the yield of monsoon sorghum grain by 2020, with worsening yields by 2050 and 2080, and warns that the IndoGangetic Plains are under threat of a significant reduction in wheat yields. Studies conducted by the Hyderabad-based Central Research Institute for Dryland Agriculture have warned that changing climate will have a negative impact on production of rice, wheat and horticulture in the country. Potato production will decline by 4 to 16 percent in West Bengal and the plateau region by 2030 . In 1995, Kullu valley apple production was one fourth comparing to the peak production of year 1989-90 after that due to impact of seasonal changes in the environment the rate of apple production was continuously decline and still the same continues. In the same way banana, coconut fruits, lemon, litchi, mango are suffered due to unseasonal heavy rainfall, flood as well as storm, wind occurred in Pondicherry washed away the trees and spoiled the harvesting. A found that 86.67 percent of the farmers had reduced over the years. Over 83 percent said there was change in climate and rainfall patterns, and 54.44 percent said the seasonal pattern was changing. The study also reported that a large number of farmers were quitting farming and shifting to other professions" (Jamwal, 2014). As per NCRB report farmers suicide in India was 10667 in 2020.

\section{Impact of Changing climate Affects Human Health}

Changing climate has a direct impact of human health. Climate changes increase the temperature fluctuation which increases warmer in temperature, rainfall, floods and droughts. Due to these natural calamities there would be high risk of creating opportunities for spreading diseases. Changing pattern of temperature increase or decrease in region provide pace to vector /mosquito borne disease like malaria, dengue, chikungunya fever, Parasitic diseases like leishmaniasis, lymphatic filariasis, onchocerisasis, tick borne diseases, Water born diseases like cholera, diarrhoeal diseases like giardiasis, salmonallosis and cryptosporidsis (Hales,e.t.al 2003) and ultra violet rays responsible for skin cancer are getting resurgence in India. At the same time changing climate impact on food creates malnutrition or less nutrition generation and finally causes attack of diseases and death.

McMichael, Intergovernmental Panel on climate Change (IPCC) says "There will be 
a severe problem of potable water and people will drink salty water. This will adversely impact pregnancy in coastal India," in the same way McMichael, a group of British scientists had carried out a survey in Bangladesh and found that surges in sea levels had started affecting pregnant women there. Mahapatra (2015) reported "We don't have any research data on India, but the situation will not be much different".

\section{Part Two:}

Climate change sub programme UNEP focuses four keys goals as adopting, mitigating, reducing emission from deforestation and forest degradation and enhancing knowledge and awareness. Recognising the knowledge towards protection of the environment is the first step of emergence of conservation of the environment. (UNEP,2009). Keeping this in view researcher tries to identify awareness and attitude towards protection of the environment among post graduate students.

\section{Objectives of the study}

- To find out the environment attitude level of post graduate students.

- To find out the significant difference between sub variable of environment attitude level of post graduate students with respect to gender.

\section{Hypotheses of the study}

- There is no significant difference between male and female post graduate students in their environment attitude level

- There is no significant difference between male and female post graduate students in their attitude towards the areas namely Health and Hygiene, Wild life, Forests, Polluters, Population Explosion, and Environmental Concern.

\section{Methodology}

In this study descriptive survey method was adopted

\section{Sample of the study}

A sample of 360 post graduate students pursuing post graduation course in the university was selected using random sampling method.

\section{Tools used in the study}

The Taj Environmental Attitude Scale (TEAS) developed by Dr. Haseen Taj (2001), Climate change awareness scale constructed by researcher was used to collect the data. The scale includes the attitude towards Health and Hygiene, Wild life, Forests, Polluters, Population Explosion, Environmental Concern. Each item alternative is assigned a weightage ranging from 4 (strongly agree) to 1 (strongly disagree) for favourable items and vice versa. The attitude score of range from 61 to 244 , higher score indicating the more favourable attitude towards environment and 
vice versa. Reliability of the scale as estimated by split half is 0.82 , which is highly significant (Larijani and Yeshodhara, 2008).

\section{Data analysis and Interpretation}

The data collected were analysed using the descriptive and differential statistics. The results were presented below [Table 1].

- The observed mean score of 360 post graduate student's awareness towards climate change and environment attitude were quite high. Post graduate students show highly aware about the polluters and its impacts on environment and human.

- Post graduate students show high awareness about climate change issues, attitude about the polluters and its impacts on environment concern and human. At the same time they show low awareness towards climate change and natural disasters, low attitude towards forests, wild life, population explosion, health and hygiene related issues.

- Student's awareness related to those issues was less compared to others areas. Many of the post graduate students don't feel forest, wildlife and its conservation and preservation greater importance for life and maintenance of bio diversity. In the same way they don't think or aware about the population explosion related problems and issues.

- It is inferred from the above table that the calculated t-value for environmental attitude of post graduate students are greater than table value (1.96) at 5\% level of significance therefore the null hypothesis is rejected. It shows that there is a significant difference between male and female students with respect to environmental attitude. Male post graduate students show high attitude than female students.

- It is inferred from the above table that the calculated t-value for environmental health and hygiene, wild life and population explosion are lesser than table value (1.96) at 5\% level of significance therefore the null hypothesis is accepted. It shows that there is no significant difference between male and female students with respect to health and hygiene, wild life and population explosion.

- It is inferred from the above table that the calculated t-value for forest, polluters and environmental concern are greater than table value (1.96) at 5\% level of significance therefore the null hypothesis is rejected. It shows that there is a significant difference between male and female students with respect to polluters and environmental concern.

\section{CONCLUSION}

In this century natural calamities and disasters become common phenomena in the world specifically in India. These phenomena make the whole world in an imbalance diversity and natural system and everyday 
human life is becoming unstable and challenging in the world. The voice rose to protect our mother world need a long way to run. From the findings of the study it is possible to see that post graduate students has awareness about most of the environmental degradation related problems and not aware of the environmental issues, forests and wildlife. Awareness should be provided to the students about environment related issues, changing climate and consequences in a high scale with their participation only a sustainable development can be achieved.

\section{REFERENCES}

[1] Hales, S. Edwards S.J, Kovats R.S. (2003). Impacts on health of climate extremes. As cited in: McMichael, A.J, Lendrum, D.H, Corvalan CF, Ebi KL, Githeko A, Scheraga JD, Woodward A, editors. Changing climate and human health: Risks and responses. Geneva, Switzerland: World Health Organization. 79-102.

[2] Indian Agriculture Industry Analysis IBEF Report (2015).

http://www.ibef.org/industry/agriculturepresentation on 21 Sep 2021.

[3] IPCC Report (2001).Working Group II: Impacts, Adaptation and Vulnerability. http://www.ipcc.ch/ipccreports/tar/wg2/ind ex.htm on 21 Sep 2021.
[4] Climate change will shake the Earth (2012).

http://www.theguardian.com/environment/ $\underline{2012 / \mathrm{feb} / 26 / \text { why-climate-change-shake- }}$ earth

[5] India - Second Biennial Update Report to the United Nations Framework convention on Climate change (2018). http://www. Moef.nic.in/sites/defult-files/vulnerabilitypk.aggarwal.pdf

[6] Jamwal, Nidhi. (2014). How Climate Change is going to affect India. . Retrieved from https://in.news.yahoo.com/howclimate-change-is-going-to-affect-india-specifically-065417794. html on 15 Sep 2021.

[7] Kumar, A. (2015). Climatic catastrophe: A threat to civilization. Environment Education and Sustainable Development. 24: 159-168.

[8] Larijani and Yeshodhara, (2008). An Empirical Study of Environmental Attitude among Higher Primary School Teachers of India and Iran. J. Human. Ecol., 24(3): 195-200.

[9] Mahapatra, R. (2015). Sea change coming... $\quad$ Retrieved from http://infochangeindia.org/ environment/coastal-nightmares/seachange-coming.html on 31 July 2021. 
[10] Meares, R. (2009). Green Business-Global warming may bring tsunami and quakes: scientists.

Retrieved fromhttp://in.reuters.com/article/2009/09/1 6/us-climate-geology-idINTRE58F62I2 $\underline{0090916}$ on 2 Aug 2021.

[11]McGuire, B.(n.n). Waking the Giant: How a Changing Climate Triggers Earthquakes, Tsunamis and Volcanoes, Oxford University Press. London.

[12] Prasad, V. (2015). Sustainable Development -Issues and Challenges in global Perspectives. Environment Education and Sustainable Development. 179-184.

[13]The Economic Survey (2014-15). Agricultural and Processed Food Products Export Development Authority (APEDA), the Department of Commerce and Industry, the Union Budget Press Releases, Media Reports,https://www.indiabudget.gov.in/e conomicsurvey/

[14]The Economic Survey (2019-20). Agricultural and Processed Food Products Export Development Authority (APEDA), the Department of Commerce and Industry , the Union Budget Press Releases, Media Reports, https://www.indiabudget.gov.in/e conomicsurvey/
[15] The Hindu (2015). Respite from heat likely from today". Retrieved from https://www.thehindu.com/news/national/r espite-from-heat-likely-fromtoday/article7252917.ece on 31 May 2021. [16] Sarkar,S.(2021). Extreme weather becomes the new normal in India's main monsoon season, Mongabay. https://india.mongabay.com/2021/10/extre me-weather-becomes-the-new-normal-inindias-main-monsoon-season/ on 25 Oct 2021.

[17] United Nations (2017) Resolution adopted by the General Assembly on 6 July 2017, Work of the Statistical Commission pertaining to the 2030 Agenda for Sustainable Development

[18] C.M. Thakar, S.S. Parkhe, A. Jain etal., 3d Printing: Basic principles and applications, Materials Today: Proceedings, https://doi.org/10.1016/j.m atpr.2021.06.272

[19] Khan, R. M. I., Kumar, T., Supriyatno, T., \&Nukapangu, V. (2021). The Phenomenon of Arabic-English Translation of Foreign Language Classes During The Pandemic. IjazArabi Journal of Arabic Learning, 4(3). https://doi.org/10.18860/ijazarabi.v4i3.1 $\underline{3597}$ 
[20] Sajja, G., Mustafa, M., Phasinam, K.,Kaliyaperumal, K., Ventayen, R., \& amp; Kassanuk, T. (2021). Towards Application of Machine Learning in Classification and Prediction of Heart Disease. 2021 Second International Conference On Electronics And Sustainable Communication Systems (ICESC).

https://doi.org/10.1109/icesc51422.2021. 9532940

[21] Veluri, R., Patra, I., Naved, M., Prasad,
Raghuvanshi, A.(2021). Learning analytics using deep learning techniques for efficiently managing educational institutes. Materials Today: Proceedings.

https://doi.org/10.1016/j.matpr.2021.11.41 $\underline{6}$

[22] UNEP Annual Report (2010).Climate Change United Nations environment programme. Retrieved from https://wedocs.unep.org/handle/20.500. $\underline{11822 / 7915 \text { on } 15 \text { Sep } 2021 .}$

V.,Arcinas, M., Beram, S., \&amp;

\begin{tabular}{|c|c|}
\hline \multicolumn{2}{|c|}{ Table 1 : Rising number of extreme Floods in the 21 ${ }^{\text {st }}$ Century } \\
\hline 2005 & Maharashtra Floods \\
\hline 2006 & Surat, Barmer and Srinagar \\
\hline 2007,2008 & Bihar Floods \\
\hline 2012 & Brahmaputra Floods \\
\hline 2013 & North India Floods \\
\hline 2014 & Kashmir Floods \\
\hline 2015 & Assam Floods, Gujarat Floods South India floods (Chennai), Uttarakhand Floods \\
\hline 2017 & Maharashtra Floods, Gujarat Floods, West Bengal Floods, Bihar Floods, North East \\
& India Floods \\
\hline 2018 & Kerala Floods \\
\hline 2019 & Floods in nine states of India \\
\hline 2020 & Assam Floods \\
\hline 2020 & Hyderabad Floods, South India floods (Chennai) \\
\hline 2021 & Uttarakhand Floods \\
\hline 2021 & Maharashtra Floods, South India floods (Chennai) \\
\hline
\end{tabular}

Table 2: Analysis scores for Environmental Awareness and Attitude of Post Graduate Students

\begin{tabular}{|c|c|c|c|c|c|c|c|c|}
\hline Variables & $\mathbf{N}$ & MEAN & SD & Gender & MEAN & SD & 't' test & Sig. \\
\hline \multirow{2}{*}{$\begin{array}{c}\text { Health and } \\
\text { Hygiene }\end{array}$} & \multirow{2}{*}{360} & \multirow{2}{*}{16.67} & \multirow{2}{*}{3.51} & Male & 16.89 & 3.53 & \multirow{2}{*}{0.479} & \multirow{2}{*}{0.489} \\
\hline & & & & Female & 16.50 & 3.50 & & \\
\hline \multirow{2}{*}{ Wild life } & \multirow{2}{*}{360} & \multirow{2}{*}{25.86} & \multirow{2}{*}{5.89} & Male & 27.32 & 5.71 & \multirow{2}{*}{0.738} & \multirow{2}{*}{0.391} \\
\hline & & & & Female & 24.76 & 5.79 & & \\
\hline \multirow{2}{*}{ Forests } & \multirow{2}{*}{360} & \multirow{2}{*}{13.77} & \multirow{2}{*}{2.94} & Male & 14.46 & 3.24 & \multirow{2}{*}{8.161} & \multirow{2}{*}{0.005} \\
\hline & & & & Female & 13.24 & 2.58 & & \\
\hline \multirow{2}{*}{ Polluters } & \multirow{2}{*}{360} & \multirow{2}{*}{63.21} & \multirow{2}{*}{11.12} & Male & 64.52 & 12.68 & \multirow{2}{*}{15.59} & \multirow{2}{*}{0.000} \\
\hline & & & & Female & 62.21 & 9.70 & & \\
\hline \multirow{2}{*}{$\begin{array}{l}\text { Population } \\
\text { Explosion }\end{array}$} & \multirow{2}{*}{360} & \multirow{2}{*}{14.54} & \multirow{2}{*}{3.08} & Male & 14.78 & 2.99 & \multirow{2}{*}{0.176} & \multirow{2}{*}{0.075} \\
\hline & & & & Female & 14.36 & 3.14 & & \\
\hline \multirow{2}{*}{$\begin{array}{c}\text { Environmental } \\
\text { Concern }\end{array}$} & \multirow{2}{*}{360} & \multirow{2}{*}{41.29} & \multirow{2}{*}{6.60} & Male & 41.72 & 6.86 & \multirow{2}{*}{1.967} & \multirow{2}{*}{0.162} \\
\hline & & & & Female & 40.97 & 6.39 & & \\
\hline \multirow{2}{*}{ Total } & 360 & 17542 & 2520 & Male & 179.70 & 26.16 & 5203 & 0027 \\
\hline & 360 & 175.42 & 25.20 & Female & 172.19 & 24.00 & 5.293 & 0.022 \\
\hline
\end{tabular}

